\title{
PENGARUH MENONTON TAYANGAN TELEVISI TERHADAP PERILAKU AGRESIF PADA ANAK PRASEKOLAH
}

\author{
Andreas Dwi Atmoko1, Zainal Munir ${ }^{2}$, Gilang Ramadhan ${ }^{3}$ \\ 1 Universitas Nurul Jadid, Probolinggo \\ 2 Universitas Nurul Jadid, Probolinggo \\ ${ }^{3}$ Dinas Kesehatan Kab.Bondowoso
}

\section{ABSTRACT}

Television is one of the mass media influence on children's behavior, especially in the process of absorption (internalization) of certain social values. This research aims to analyze The influence of Watching Television Towards Aggressive Behavior to Preschool Children in TK Aisyah Bondowoso. Design of research using the analytic of correlation with Cross Sectional approach. The population is Preschool Children in TK Aisyah Bondowoso and sample as many as 30 respondents in methods data retrieval of Total Sampling. This research was conducted in October 2015. Data collection was conducted by questionnaire sheet, then the data is tabulated and analysed using the statistical analysis Test correlation Spearman Rho ' with significant degrees of 0,05. So the obtained $p$ value 0.008 meaning $H I$ received there is the influence of Watching Television towards aggressive behavior in Preschool Children in TK Aisyah Bondowoso value correlation $r=0439$.The important of knowledge The influence of Watching Television Towards Aggressive Behavior in Preschool Children in TK Aisyah Bondowoso. So for need role of parents to prevent aggressive behavior.

Keywords: Watch Television, Aggressive Behavior, Pre School Children.

\section{ABSTRAK}

Televisi merupakan salah satu media massa yang berpengaruh terhadap perilaku anak terutama dalam proses penyerapan (internalisasi) nilai-nilai sosial tertentu. Penelitian ini bertujuan menganalisa Pengaruh Menonton Tayangan Televisi terhadap Perilaku Agresif pada Anak Prasekolah di TK Aisyah Bondowoso. Desain penelitian yang digunakan adalah analitik dengan pendekatan Cross Sectional. Populasi adalah Anak Prasekolah di TK Aisyah Bondowoso dan sampel sebanyak 30 responden dengan metode pengambilan data secara Total Sampling. Penelitian ini dilakukan pada bulan Oktober 2015. Pengumpulan data dilakukan dengan lembar kuesioner, kemudian data ditabulasi dan dianalisa menggunakan analisa statistik Uji korelasi Spearman Rho' dengan taraf signifikan 0,05. Sehingga didapatkan $p$ value 0,008 yang berarti H I diterima dan ada Pengaruh Menonton Tayangan Televisi terhadap Perilaku Agresif pada Anak 
Jurnal Keperawatan Profesional (JKP)

Volume 7, Nomor 1 Februari 2019

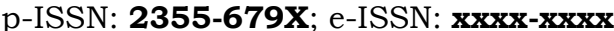

https://ejournal.unuja.ac.id/index.php/jkp/index

Prasekolah di TK Aisyah Bondowoso dengan nilai korelasi $r=0,439$. Pentingnya pengetahuan Pengaruh Menonton Tayangan Televisi terhadap Perilaku Agresif pada Anak Prasekolah di TK Aisyah Bondowoso. Sehingga anak mrmbutuhkan peran orang tua untuk mencegah perilaku agresif.

Kata kunci: Menonton Televisi, Perilaku Agresif, Anak Usia Pra Sekolah. 


\section{PENDAHULUAN}

Dalam kehidupan sekarang ini mengucapkan salam dirasa lebih sulit dari berkata kotor, perpecahan rumah tangga akibat KDRT seperti menjadi hal yang lumrah, bertengkar dengan tetangga sekelumit permasalahan lain yang berkenaan dengan akhlaq. Hal ini sebenarnya tidak akan terjadi jika manusia itu sendiri belajar dari apa yang sudah dicontohkan oleh Rasulullah.

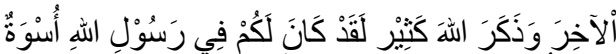

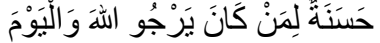

"Sesungguhnya pada diri Rasulullah ada teladan yang baik bagimu, yaitu bagi orang yang mengharap Allah dan hari akhir serta banyak berdzikir kepada Allah.”

(Al-Ahzab:21)

Televisi merupakan media elektronik yang sangat akrab bagi anakanak, karena banyak film yang menayangkan program acara menarik untuk anak-anak. Media anak-anak, khususnya televisi, merupakan salah satu media penting bagi anak-anak dalam proses penyerapan (internalisasi) nilai-nilai sosial tertentu di masyarakat. Walaupun televisi hanya satu dari banyak media massa yang mempengaruhi perilaku anak, televisi adalah yang paling berpengaruh Riset terbaru membuktikan bahwa manusia menghabiskan minimal 600 hingga 700 $\mathrm{jam} /$ tahun untuk menonton televisi. Anak balita yang belum bersekolah mencapai tingkat yang mengkhawatirkan, yaitu 22,9 jam perminggu dihabiskan untuk ini. Sedang anak-anak usia sekolah (6-11 tahun), menghabiskan 20,4 jam perminggunya. Bahkan riset yang lain mengatakan hal yang lebih parah, yaitu balita usia prasekolah rata-rata menonton layar televisi selama 54 jam perminggunya. Durasi menonton yang begitu lama, dan kualitas tayangan yang disodorkan oleh televisi, sangat berbahaya bagi pembinaan akhlak anak. Apalagi kini intensitas acaraacara berbau kekerasan bertambah banyak.
Menurut penelitian Yayasan Pengembangan Media Anak (YPMA) pada tahun 2002-2006 terjadi peningkatan jumlah jam menonton tayangan televisi pada anak yaitu sebesar 28,57\%-33,33\%. Lebih dari 20 episode tentang kekerasan ditampilkan setiap jam pada program televisi anak-anak, dan diperkirakan jumlah ini akan mencapai ribuan saat anak-anak ini mencapai usia remaja. Sementara itu, beberapa peneliti di Amerika Serikat melakukan penelitian tentang hubungan antara adegan kekerasan yang ditonton dengan agresif pada anak taman kanakkanak.

Peneliti menemukan fenomena pada bulan November 2015 di TK Aisyiah Bondowoso yaitu pada seorang anak lakilaki usia 4 tahun sering berkata kasar dan seorang lagi anak laki-laki usia 5 tahun, mengajak temannya untuk berkelahi saat bermain. Setelah peneliti mengklarifikasi kedua anak tersebut, anak I menjadi marah dan memaki, anak II menjawab hanya ingin menirukan gerakan tokoh kartun yang ditontonnya. Peneliti juga bertanya pada ibu anak tersebut tentang respon ibu saat anaknya berlaku demikian, ibu anak I menjawab hanya memperingatkan anaknya, sedangkan ibu anak II tidak menegur atau memarahi anaknya. Kemudian peneliti bertanya tentang lama dan jenis tayangan televisi yang ditonton anak di rumah, ibu anak I dan II menjawab bahwa anaknya menonton sekitar 3 jam dalam sehari dan jenis tayangannya kebanyakan kartun dan sinetron laga.

Disinilah peran perawat sebagai pemberi informasi sangat dibutuhkan. Perawat dapat memberikan informasi tentang pengaruh tayangan televisi terhadap perilaku agresif pada anak usia prasekolah sehingga dengan demikian orang tua dapat memahami dan meminimalkan pengaruh televisi.

Dari latar belakang di atas, maka peneliti tertarik untuk meneliti "Pengaruh Tayangan Televisi Terhadap Perilaku Agresif Pada Anak Usia Prasekolah di TK Aisyiah Bondowoso" 


\section{METODE PENELITIAN}

Design Penelitian. Desain penelitian yang digunakan dalam penelitian ini adalah Analitik Korelasional dengan pendekatan Cross Sectional. Populasi dalam penelitian ini adalah anak prasekolah di TK Aisyiah Bondowoso sebanyak 30 orang. Sampel dalam penelitian ini adalah anak prasekolah di TK Aisyah Bondowoso sejumlah 30 sampel. Tehnik Sampling yang digunakan dalam penelitian adalah Total Sampling. Penelitian ini dilakukan pada bulan Oktober 2015.

Prosedur Penelitian. Permintaan izin penelitian ke STIKes Nurul Jadid Paiton Probolinggo. Mengirim surat permohonan izin ke TK Aisyiah Bondowoso. Mendapat ijin dari TK Aisyiah Bondowoso. Menentukan sampel penelitian dengan menggunakan teknik total sampling. Memberi penjelasan kepada calon responden perihal penelitian yang akan dilakukan. Bila calon responden bersedia, maka calon responden diminta menandatangani surat pertanyaan bersedia menjadi responden. Responden diminta mengisi kuesioner kemudian dikumpulkan kembali kepada peneliti. Mengolah data ke dalam sistem computer SPSS
Analisis Data. Analisis data menggunakan analisis univariat dan bivariat menggunakan "Korelasi Spearman rho".

\section{HASIL PENELITIAN}

Tabel 1. Distribusi Frekuensi Responden Tayangan Televisi di TK Aisyiah Bondowoso

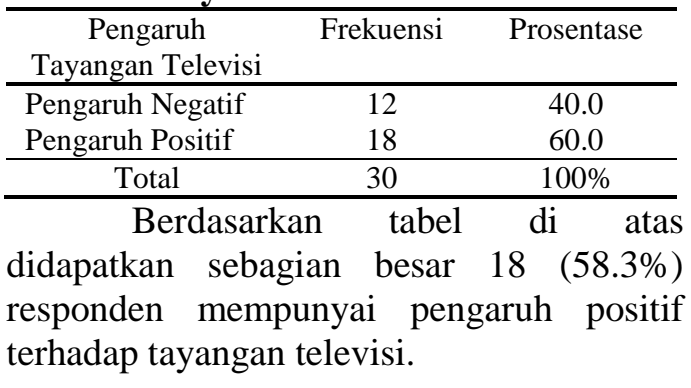

Tabel 2. Distribusi Frekuensi Responden Perilaku Agresif di TK Aisyiah Bondowoso

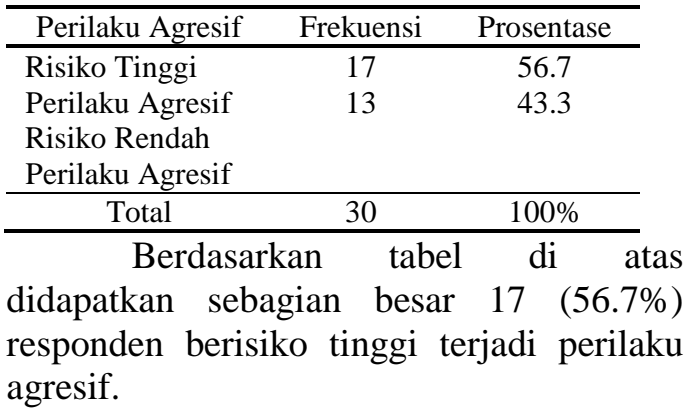

Tabel 3. Tabulasi Silang Pengaruh Tayangan Televisi dengan Perilaku Agresif di TK Aisyiah Bondowoso

\begin{tabular}{ccccccc}
\hline \multirow{2}{*}{ Tabulasi Silang } & \multicolumn{4}{c}{ Perilaku Agresif } & \multicolumn{2}{c}{ Total } \\
\cline { 2 - 5 } & \multicolumn{2}{c}{ Risiko tinggi perilaku agresif } & $\begin{array}{c}\text { Risiko rendah perilaku } \\
\text { agresif }\end{array}$ & & \\
\hline Menonton Televisi & $\mathrm{N}$ & $\%$ & $\mathrm{~N}$ & $\%$ & $\mathrm{~N}$ & $\%$ \\
\hline Pengaruh Negatif & 10 & 33,3 & 2 & 6,6 & 12 & 40 \\
\hline Pengaruh Positif & 7 & 23,5 & 11 & 36,7 & 18 & 60 \\
\hline Total & 17 & 56,7 & 13 & 43,3 & 30 & 100 \\
\hline
\end{tabular}

Berdasarkan tabel di atas didapatkan bahwa responden yang memiliki pengaruh negatif dengan risiko tinggi perilaku agresif seabanyak 10 orang $(33,3 \%)$ dan responden dengan risiko rendah perilaku agresif sebanyak 2 orang $(6,6 \%)$. Sedangkan responden yang pengaruh positif dengan risiko tinggi perilaku agresif sebanyak 7 orang $(23,5 \%)$ dan responden dengan risiko rendah perilaku agresif sebanyak 11 $(36,7 \%)$.

\section{a. Uji Korelasi Spearman rho'}

Tabel 4 Identifikasi Pengaruh Tayangan Televisi Terhadap Perilaku Agresif Pada Anak Usia Prasekolah di TK Aisyiah Bondowoso 


\begin{tabular}{ccccc}
\hline $\begin{array}{c}\text { Variabel } \\
\mathbf{1}\end{array}$ & $\begin{array}{c}\text { Variabel } \\
\mathbf{2}\end{array}$ & $\begin{array}{c}\text { Nilai } \mathbf{r} \\
\text { hitung }\end{array}$ & $\begin{array}{c}\boldsymbol{P} \\
\text { Value }\end{array}$ & $\mathbf{N}$ \\
\hline $\begin{array}{c}\text { Menonton } \\
\text { Tayangan } \\
\text { Televisi }\end{array}$ & $\begin{array}{c}\text { Perilaku } \\
\text { Agresif }\end{array}$ & 0,439 & 0,008 & 30 \\
\hline
\end{tabular}

Berdasarkan tabel di atas untuk nilai $\rho$ value $<\rho$ alpha yaitu $0.008<0.05$, dengan nilai korelasi ( $r=0.439$ ) yang berarti ada Pengaruh Tayangan Televisi Terhadap Perilaku Agresif Pada Anak Usia Prasekolah di TK Aisyiah Bondowoso.

\section{PEMBAHASAN}

\section{Menonton Tayangan Televisi.}

Berdasarkan tabel 1 peneliti menyebutkan bahwa pengaruh menonton televisi memiliki pengaruh positif terhadap perilaku agresih Anak Usia Pra Sekolah di TK Aisyiah Bondowoso, sebesar 18 $(60.0 \%)$, sedangkan pengaruh negatif sebesar $12(40.0 \%)$.

Televisi merupakan media elektronik yang sangat akrab bagi anakanak, karena banyak film yang menayangkan program acara menarik untuk anak-anak. Televisi adalah suatu perlengkapan elektronis, yang pada dasarnya adalah sama dengan gambar hidup yang meliputi gambar dan suara. Televisi merupakan gabungan dari media gambar yang bisa bersifat politis, informatif (information), hiburan (entertaiment) dan pendidikan (education), atau bahkan gabungan dari keempat unsur tersebut.

Anak usia pra sekolah memiliki keterbatasan daya nalar, daya fantasi yang besar dan ketidakmampuan membedakan antara khayalan dan kenyataan, serta kurangnya penjelasan yang rasional dari orang tua atau orang dewasa di sekitar mereka, akibatnya mereka percaya bahwa tayangan tersebut adalah realita.

Hal ini didukung oleh pendapat peneliti yang lain bahwa lingkungan sosial seperti lingkungan keluarga dan temanteman memiliki hubungan nyata dengan terpaan media televisi pada anak. Ketika menonton televisi, biasanya anak didampingi oleh orang tua atau keluarga. Maka dapat dikatakan bahwa semakin sering suatu keluarga menonton televisi maka semakin sering pula anak menonton televisi dan sebaliknya semakin jarang suatu keluarga menonton televisi, maka semakin jarang pula seorang anak menonton televisi.

Hal ini didukung oleh pendapat peneliti yang lain bahwa pada fase intuituf atau praoperasional (umur 2-7 tahun), ini anak sudah tidak lagi terikat oleh lingkungan, ia mulai mengembangkan berbagai tanggapan mental yang terbentuk dalam fase sebelumnya. Fase ini kemampuan menyimpan tanggapan bertambah besar.

Ini didukung pula oleh pendapat peneliti sebelumnya bahwa untuk kategori usia, disebutkan bahwa semakin rendah usia khalayak maka semakin rendah pula motivasi menonton televisi mereka, dan semakin tinggi usia khalayak berarti semakin mereka membutuhkan informasi dari televisi. Pernyataan diatas yang mengemukakan bahwa semakin rendah usia seseorang memiliki motivasi menonton yang rendah tidak selamanya benar. Khalayak yang memiliki usia prasekolah dan sekolah dasar biasanya memiliki motivasi menonton yang sangat tinggi. Jumlah jam menonton mereka lebih tinggi dibandingkan jumlah kegiatan mereka yang lain seperti belajar.

Didukung oleh teori peneliti sebelumnya bahwa pengalaman pribadipun dapat digunakan sebagai upaya memperoleh pengetahuan dengan cara mengulang kembali pengalaman yang pernah diperoleh dalam memecahkan permasalahan yang dihadapi masa lalu.

Berdasarkan pendapat-pendapat para ahli tersebut, peneliti memperoleh gambaran bahwa menonton tayangan televisi tanpa bimbingan dari orang tua akan berpengaruh terhadap pembentukan karakter anak terutama pada usia pra sekolah di TK Aisiyah Bondowoso. Semakin rendah bimbingan/pengawasan orang tua terhadap anak, maka semakin tinggi pengaruh positif dampak tayangan televisi bagi anak.

Menurut peneliti menonton tayangan televisi memiliki pengaruh yang sedang terhadap Anak Usia Pra Sekolah di TK Aisyiah Bondowoso. Hal ini 
dikarenakan oleh tingkat pendidikan. Semakin rendah tingkat pendidikan orang tua, maka keasadaran akan perhatian terhadap anak juga berpengaruh terhadap anak pra sekolah.

Perilaku Agresif. Berdasarkan Berdasarkan tabel 3 peneliti menyebutkan bahwa risiko tinggi perilaku agresif terhadap Anak Usia Pra Sekolah di TK Aisyiah Bondowoso, sebesar 17 (56.7\%), sedangkan risiko rendah perilaku agresif sebesar 13 (43.3\%).

Seorang peneliti dan penulis buku tentang perilaku agresif, mendefinisikan agresif sebagai segala bentuk perilaku yang dimaksudkan untuk menyakiti seseorang, baik secara fisik amupun mental. Perilaku agresif pada umumnya dipahami sebagai perilaku yang dimaksudkan untuk merugikan atau melukai orang lain.

Agresif fisik terdiri dari menendang, memukul, mendorong, menusuk dan menembak. Merusak properti, akibat vandalism atau perusakan yang disengaja, juga termasuk dalam kategori agresi ini.

Perilaku agresif secara verbal memiliki cirri-ciri, antara lain adanya penggunaan bahasa yang kasar, sering bertengkar mulut, mengeritik dengan pedas, menghina dan memanggil orang lain dengan nama-nama yang tidak disukai oleh orang lain. Sedangkan ciri-ciri perilaku agresif secara fisik atau non verbal antara lain menggigit, menendang, memberontak, menggangu, merusak, mendorong, menyerang, mendominasi, berkelahi memukul serta perilaku destruktif lain yang mengganggu kesenangan dan ketenangan orang lain.Berdasarkan pendapat-pendapat para ahli tersebut, peneliti memperoleh gambaran bahwa menonton tayangan televisi tanpa bimbingan dari orang tua akan berpengaruh terhadap pembentukan karakter anak terutama pada usia pra sekolah di TK Aisiyah Bondowoso. Semakin rendah bimbingan/pengawasan orang tua terhadap anak, maka semakin tinggi pengaruh positif dampak tayangan televisi bagi anak.

\begin{tabular}{llr}
\multicolumn{2}{c}{ Agresif adalah segala bentuk } \\
perilaku yang dimaksudkan untuk \\
menyakiti & seseorang, baik secara fisik
\end{tabular}

amupun mental. Perilaku agresif pada umumnya dipahami sebagai perilaku yang dimaksudkan untuk merugikan atau melukai orang lain. Faktor dari dalam berupa hambatan atau daya fantasi tinggi dan luar diri anak berupa contoh agresif dari lingkungan dan tayangan yang bertema kekerasan akan mempengaruhi perilaku agresif.

Sedangkan Peneliti lain berpendapat bahwa keluarga merupakan bagian lingkungan sosial yang paling sering menonton bersama dengan anak. Oleh karena itulah keluarga lebih mampu untuk mengontrol terpaan media televisi dibandingan lingkungan sekolah maupun tetangga/ teman sepermainan. Selain itu, anak TK cenderung masih sangat menuruti perkataan orang tua/keluarganya. Didukung juga oleh pendapat Kuswarno bahwa bagi anak-anak yang cukup mengerti dan diberi pengarahan oleh orang tua mereka, maka mereka cenderung untuk tidak terpengaruh atau meniru. Lain halnya dengan khalayak anak-anak yang tidak memperoleh pembinaan dari orang tuanya maka cenderung untuk meniru. Artinya bahwa peranan keluarga dan latar belakang keluarga menentukan pembentukan persepsi seseorang.

Hal ini didukung oleh pendapat para peneliti, perilaku agresif itu didapat anak karena ada contoh dari lingkungan sekitarnya, bisa orang tua, paman, bibi atau saudara kandung maupun temannya sendiri.Jadi, perilaku agresif itu karena mereka pelajari dari sekitarnya.

Hal ini sesuai dengan teori peneliti yang lain, keluarga adalah lingkungan yang paling dekat dengan anak. Banyaknya waktu yang dihabiskan anak prasekolah bersama keluarga lebih banyak dibandingkan dengan waktu yang dihabiskan di sekolah maupun bersama tetangga/teman sepermainnya. Selain itu keluarga merupakan bagian lingkungan sosial yang paling sering menonton bersama dengan anak. Oleh karena itulah keluarga lebih mampu untuk mengontrol terpaan media televisi dibandingkan lingkungan sekolah maupun tetangga/ teman sepermainan. Selain itu, anak 
prasekolah cenderung masih sangat menuruti perkataan orang tua/keluarganya.

Berdasarkan pendapat peneliti sebelumnya, secara singkat pengaruh adegan kekerasan dalam tayangan televisi terhadap anak adalah (1)Observed Aggression, pada tahap ini, anak melakukan observasi (pengamatan) tentang tayangan kekerasan; (2)Disinhibition, adalah berkurangnya rintangan atau hambatan atau kemampuan untuk menahan diri; (3)Desensitization, adalah kondisi berkurangnya atau hilangnya kepekaan atau reaksi emosional. Dengan demikian, akan terjadi reaksi yaitu film kekerasan mengajarkan agresi; (4) Habitualization, jika seorang anak terlalu sering menyaksikan tayangan kekerasan, mereka akan terbiasa dengan kekerasan tersebut sehingga melihatnya sebagai hal yang biasa saja.

Hal ini karena anak prasekolah yang menonton televisi lebih sedikit, maka akan lebih banyak punya waktu luang untuk melakukan kegiatan di luar rumah seperti bermain dengan temannya. Sehingga pengaruh televisi yang menyajikan kekerasan lebih sedikit dikonsumsi oleh anak. Oleh karena itu, anak tidak akan terpapar dan kejadian perilaku agresif bisa diminimalisir.

Berdasarkan pendapat para ahli tersebut, peneliti memperoleh gambaran bahwa perialku agresif bagi anak dapat dipengaruhi oleh faktor eksternal yang salah satunya menonton televisi tanpa bimbingan dari orang tua akan berpengaruh terhadap pembentukan karakter anak terutama pada usia pra sekolah di TK Aisiyah Bondowoso.

Menurut peneliti perilaku agresif memiliki pengaruh yang sedang terhadap Anak Usia Pra Sekolah di TK Aisyiah Bondowoso. Hal ini dikarenakan oleh bimbingan dan pengawasan orang tua terhadap tayangan televisi yang semakin lama semakin bebas. Semakin rendah tingkat pengawasan orang tua terhadap anak, maka perilaku anak berpengaruh terhadap pergaulan di lingkungan sekitarnya.
Pengaruh Tayangan Televisi Terhadap

Perilaku Agresif Pada Anak Usia Prasekolah di TK Aisyiah Bondowoso. Berdasarkan uji spearman rho dengan menggunanakan SPSS dapat dilihat bahwa hasil penelitian Pengaruh Tayangan Televisi Terhadap Perilaku Agresif Pada Anak Usia Prasekolah di TK Aisyiah Bondowoso menunjukkan pengaruh yang positif. Hal ini dibuktikan dengan interpretasi nilai $r$ sebesar 0.439 , dan nilai $r$ tersebut diinterpretasikan memiliki hubungan yang sedang, yang artinya semakin tinggi pengaruh positif menonton televisi maka semakin tinggi pula risiko perilaku agresif pada Anak Usia Pra Sekolah di Tk Aisiyah Bondowoso. Hasil uji statistik diperoleh $p$ value $<\alpha(0.008<$ 0.05), maka dapat disimpulkan bahwa ada pengaruh yang signifikan antara Pengaruh Tayangan Televisi Terhadap Perilaku Agresif Pada Anak Usia Prasekolah di TK Aisyiah Bondowoso.

Televisi merupakan media elektronik yang sangat akrab bagi anakanak, karena banyak film yang menayangkan program acara menarik untuk anak-anak. Televisi adalah suatu perlengkapan elektronis, yang pada dasarnya adalah sama dengan gambar hidup yang meliputi gambar dan suara. Televisi merupakan gabungan dari media gambar yang bisa bersifat politis, informatif (information), hiburan (entertaiment) dan pendidikan (education), atau bahkan gabungan dari keempat unsur tersebut.

Tayangan televisi, terutama yang mengandung unsur kekerasan merupakan salah satu faktor pencetus munculnya perilaku agresif pada anak usia pra sekolah. Durasi menonton yang begitu lama, dan kualitas tayangan yang disodorkan oleh televisi, sangat berbahaya bagi pembinaan akhlak anak. Namun, beberapa faktor juga dapat mempengaruhi proses pembentukan perilaku agresif seperti jenis tayangan televisi dan faktor keluarga.

Selain itu, menururut pendapat peneliti sebelumnya bahwa anak-anak seharusnya hanya menonton televisi selama 1,5 jam per hari atau paling lama dua jam per hari. Sehingga mereka punya lebih banyak waktu luang untuk mengerjakan 
tugas rumah atau yang lainnya. Didukung juga oleh pendapat peneliti yang lain bahwa durasi menonton yang begitu lama, dan kualitas tayangan yang disodorkan oleh televisi, sangat berbahaya bagi pembinaan akhlak anak. Apalagi kini intensitas acaraacara berbau kekerasan bertambah banyak.

Hal ini sejalan dengan pendapat peneliti terdahulu bahwa anak cenderung hanya menonton acara televisi yang menghibur seperti film kartun dan film anak lainnya. Jarang sekali anak yang suka menonton acara televisi yang bersifat informatif seperti berita. Tayangan kekerasan itu akan menimbulkan suatu kesan dan membuat suatu persepsi tersendiri bagi khalayak khususnya anakanak.

Hal ini didukung pula oleh pendapat peneliti sebelumnya bahwa anak usia pra sekolah memiliki pola pikir egosentris. Mereka belum mampu membedakan obyek serta belum mampu berpikir secara bolak-balik, imajinatif dan rasional. Anak usia pra sekolah juga memiliki keterbatasan daya nalar, daya fantasi yang besar dan ketidakmampuan membedakan antara khayalan dan kenyataan, serta kurangnya penjelasan yang rasional dari orang tua atau orang dewasa di sekitar mereka, akibatnya mereka percaya bahwa tayangan tersebut adalah realita. Selain itu, ketidakmampuan anak usia pra sekolah menghubungkan antara tindakan, motivasi, bertindak dan konsekuensi tindakan. Jika seorang anak terlalu sering menonton tayangan kekerasan, maka kekerasan akan menjadi hal yang biasa bagi anak. Akibatnya, anak akan kehilangan kepekaan (desensitized) sehingga mereka tidak lagi memiliki perasaan bersalah atau takut untuk melakukan kekerasan.

Bagi anak-anak yang cukup mengerti dan diberi pengarahan oleh orang tua mereka, maka mereka cenderung untuk tidak terpengaruh atau meniru. Lain halnya dengan khalayak anak-anak yang tidak memperoleh pembinaan dari orang tuanya maka cenderung untuk meniru. Artinya bahwa peranan keluarga dan latar belakang keluarga menentukan pembentukan persepsi seseorang.
Seorang peneliti dan penulis buku tentang perilaku agresif, mendefinisikan agresif sebagai segala bentuk perilaku yang dimaksudkan untuk menyakiti seseorang, baik secara fisik amupun mental. Perilaku agresif pada umumnya dipahami sebagai perilaku yang dimaksudkan untuk merugikan atau melukai orang lain.

Dari hasil penelitian tersebut juga didapatkan bahwa responden yang memiliki pengaruh negatif berjumlah 12 pasien (40.0\%), pengaruh positif berjumlah 18 pasien $(60.0 \%)$. Sedangkan responden yang berisiko tinggi terjadi perilaku agresif berjumlah 17 pasien (56.7\%), berisiko rendah terjadi perilaku agresif berjumlah 13 pasien (43.3\%).

\section{KESIMPULAN DAN SARAN \\ Kesimpulan}

1. Menonton tayangan televisi pada anak usia pra sekolah di TK Aisiyah Bondowoso sebagian besar mendapat pengaruh positif yang berjumlah 18 responden (58.3\%).

2. Perilaku agresif pada anak usia pra sekolah di TK Aisiyah Bondowoso sebagian besar berisiko tinggi perilaku agresif berjumlah 17 responden $(56.7 \%)$.

3. Ada Pengaruh antara Tayangan Televisi Terhadap Perilaku Agresif Pada Anak Usia Prasekolah di TK Aisyiah Bondowoso.

\section{Saran}

1. Penulis

Penulis memperoleh wawasan dan pengetahuan tentang Pengaruh Tayangan Televisi Terhadap Perilaku Agresif Pada Anak Usia Prasekolah di TK Aisyiah Bondowoso. Serta dapat digunakan sebagai bekal untuk melaksanakan penelitian selanjutnya dengan hasil yang baik.

2. Responden Memberikan informasi dan menambah pengetahuan kepada orang tua responden dalam membimbing anak pada usia pra sekolah.

3. Institusi Pendidikan

Bagi institusi pendidikan Fakultas Ilmu Kesehatan Prodi S-1 Keperawatan 
sebagai bahan masukan dan referensi dalam penelitian lebih lanjut.

4. Penelitian lebih lanjut Dapat dijadikan penelitian lebih lanjut mengenai manajemen penanganan Pengaruh Tayangan Televisi Terhadap Perilaku Agresif Pada Anak Usia Prasekolah di TK Aisyiah Bondowoso.

\section{DAFTAR PUSTAKA}

1. Ahmadi, Abu; Sholeh, Munawar. 2005. Psikologi Perkembangan. Jakarta: PT Rineka Cipta

2. Akbar, Reni. 2009. Perkembangan Anak : Mengenal Sifat, Bakat dan Kemampuan Anak Edisi 3. Jakarta : Gramedia Widia Sarana Indonesia

3. Ananta, Sari. 2006. Menyikapi Perilaku Agresif Anak. Yogyakarta :Kanisius

4. Arifin, Azus. 2007. Menjadi Ayah. Solo: Samudera

5. Arikunto, Suharsimi. 2000. Manajemen Penelitian. Jakarta : Rineka Cipta

6. Dariyo, Agoes. 2007. Psikologi Perkembangan Anak Tiga Tahun Pertama (Psikologi Atitama). Bandung : PT. Refika Aditama

7. Hardayani, Wibi. 2007. Perkembangan Anak Edisi Ketujuh Jilid Dua. Jakarta: Erlangga

8. Hidayat, A.(2007). Metode Penelitian Keperawatan dan Teknik Analisis data. Jakarta: Selemba Medika.

9. Kurniasih, Eko. 2008. Perilaku Menonton Tayangan Televisi. Jakarta: ECG

10. Kuswarno, Engkus. 2007. Hubungan Karakteristik Demografis dengan Motif Kognitif dan Afektif Penggunaan Radio dan Televisi pada Masyarakat Padasuka, Kabupaten Sukabumi, Jawa Barat. Tesis: Sekolah Pasca Sarjana IPB.

11. Lina, Jusuk. 2003. Mendidik dan Menerapkan Disiplin pada Anak Prasekolah. Jakarta : Gramedia Pustaka Utama

12. Morissan. 2008. Manajemen Media Penyiaran : Strategi Mengolah Radio dan Televisi. Jakarta: Kencana Prenada Media Grup

13. Munir, Z. (2017). Analisis pengaruh Pendidikan, Pendapatan dan Pekerjaan terhadap Motivasi Orangtua dalam Kualitas Perawatan Anak dengan HIV/AIDS. Universitas Muhammadiyah Jakarta.

14. Munir, Z. (2018). Mendidikan Kids Zaman Now" Menjawab Pergeseran Peradaban. Surabaya.

15. Nazir, M. 2005. Metode Penelitian. Bogor: Ghalia Indonesia

16. . 2011. Buku Ajar: Metodologi

Penelitian Kesehatan. Konsep

Pembuatan Karya Tulis dan Thesis untuk Mahasiswa Kesehatan. Yogyakarta: Nuha Medika

17. Notoatmodjo, Soekidjo. 2008. Pengantar Pendidikan dan Perilaku Kesehatan. Jakarta: Rineka Cipta

18. Nursalam. 2001. Pendekatan Praktis Metodologi Riset Keperawatan. Jakarta : Sagung Seto

19. 2008. Konsep dan Penerapan Metodologi Peneltiian Ilmu Keperawatan : Pedoman Skripsi, Tesis, dan Instrumen Penelitian Keperawatan. Jakarta : Salemba Medika

20. Patterson, Charlotte J. 2008. Child Development. New York : McGrawHill Companies

21. Patmonodewo, Soemiarti. 2005. Pendidikan Anak Prasekolah. Jakarta: RinekaCipta

22. (QS. Al-Ahzab: 21)

23. Rakhmat, Jalaludin. 2000. Psikologi Komunikasi. Jakarta: Bina Rupa Aksara

24. Rimm, Sylvia. 2003. Mendidik dan Menerapkan Disiplin Pada Anak Prasekolah: Pola Asuh Anak Masa Kini. Jakarta : Gramedia Pustaka Utama

25. Santoso, Sugeng. 2004. Kesehatan dan Gizi. Jakarta :Rineka Cipta

26. Sunarto. 2009. Televisi, Kekerasan dan Perempuan. Jakarta : PT. Kompas Media Nusantara

27. Sugiyono. 2003. Statistika Untuk Penelitian. Bandung : CV Alfabeta 
28. Sarjono. 2009. Pola Menonton Sinetron dan Perilaku Etis Remaja: Studi Kasus Bertemakan Remaja di Televisi. Skripsi: IPB

29. Wahab, Samik. 2000. Ilmu Kesehatan Anak Nelson Volume I Edisi 15. Jakarta : EGC

30. Yusuf, Syamsu. 2008. Psikologi Perkembangan Anak\& Remaja. Bandung : PT Remaja Rosdakarya

31. Zuriah, Nurul. 2006. Metodologi Penelitian Sosial dan Pendidikan. Jakarta: Bumi Aksara

32. Agus dan Sinta. 2009. Bahaya Tontonan Kekerasan pada Anak. http://www.resep.web.id, diunduh tanggal 4 April 2015, jam 18.00 WIB

33. Frizal, Jamrida. 2009. Tinjauan Teoritis tentang Persepsi Siswa tentang Media Televisi dan Pengaruhnya terhadap Perubahan Perilaku Siswa. http://www.scribd.com, diunduh pada tanggal 24 Maret 2015, jam 20.00 WIB

34. Miarso, Hadi. 2004. Hakikat Televisi Dalam Media Pendidikan. Http://Definisi-Televisi.Pdf, Diunduh Pada Tanggal 4 Mei 2015, Jam 11.00 Wib

35. Setiawan, Atang. 2005. Mengatasi Perilaku Agresif Pada Siswa. File.Upi.Edu/Direktori/Fip/Jur._Pend. Luar_Biasa/195604121983011/Atang Setiawan/Pendidikan_Atl/Makalah_An ak Agresif.Pdf.Diunduhpadatanggal 21 Mei 2015, Jam 20.00 Wib

36. Surbakti. 2008. Awas Tayangan Televisi Tayangan Misteri dan Kekerasan Mengancam anak anda.Jakarta. PT. Gramedia. 